\title{
TWO NEW SPECIES OF CELTIS (CELTIDACEAE) FROM AUSTRALIA AND MADAGASCAR
}

\author{
A. SATTARIAN \& L.J.G. VAN DER MAESEN \\ Nationaal Herbarium Nederland, Wageningen University branch (Herbarium Vadense), \\ Generaal Foulkesweg 37, 6703 BL Wageningen, The Netherlands; \\ e-mail: Ali.Sattarian@wur.nl
}

\section{SUMMARY}

Celtis australiensis Sattarian is described from Australia and Celtis madagascariensis Sattarian is new for Madagascar. Both new Celtidaceae (formerly Ulmaceae-Celtidoideae) are illustrated with a photograph.

Key words: Celtis, Australia, Madagascar, endocarp surface, leaf margin, leaf shape, taxonomy.

Celtidaceae (formerly Ulmaceae-Celtidoideae) comprise c. 150 species classified in 9 genera (e.g., Celtis, Trema) distributed in the Northern Hemisphere and in Africa, to Southern Africa (Polhill, 1964; Grudzinskaya, 1967; Elais, 1970; Terabayashi, 1991; Omori \& Terabayashi, 1993; Judd et al., 1994; Ueda et al., 1997). Some species of the family are used for timber and reforestation, some are ornamental.

One of the species of Celtis so far known as widespread, C. philippensis Blanco, was supposed to be distributed in Tropical Africa and Madagascar, India, Burma, South East China, Taiwan, Indochina, Thailand, throughout Malesia to North East and West Australia and the Solomons (Soepadmo, 1977). Soepadmo distinguished two varieties: C. philippensis var. philippensis and C. philippensis var. wightii, and noted they may not be clearly defined. While going through various herbarium collections from Africa, Asia, Australia, and Madagascar, we found two new species of Celtis, easily recognised by habit, leaf shape, leaf margin, and endocarp of fruits. The author of the Ulmaceae for the Flora of Australia, Hewson (1989) also remarked that some Australian specimens did not fit in C. philippensis. We are of the opinion that the "C. philippensis complex" has to be divided into several regional species, and C. philippensis s.s.

\section{Celtis australiensis Sattarian, spec. nov. - Fig. 1}

$\mathrm{Ab}$ C. philippensis differt foliis elliptico-cordatis, margine et apice spinosis, pilosis (unicellulosis praecipue in pagina inferiore). - Typus: Telford 11722 (holo CBG; iso BISH, BRI, L, NSW, PERTH), Western Australia, Dampier district, Geikie Gorge, near gorge mouth, 14 May 1992, fr.

Small tree or shrub 2-4 m tall, bark smooth, white to grey. Leaves alternate, simple, elliptic-cordate, $2-7$ by $1.5-5 \mathrm{~cm}$, coriaceous, margin either entire or with spines along the upper half of the margin, petiole short, $3-5 \mathrm{~mm}$, with hairs, apex apiculate 


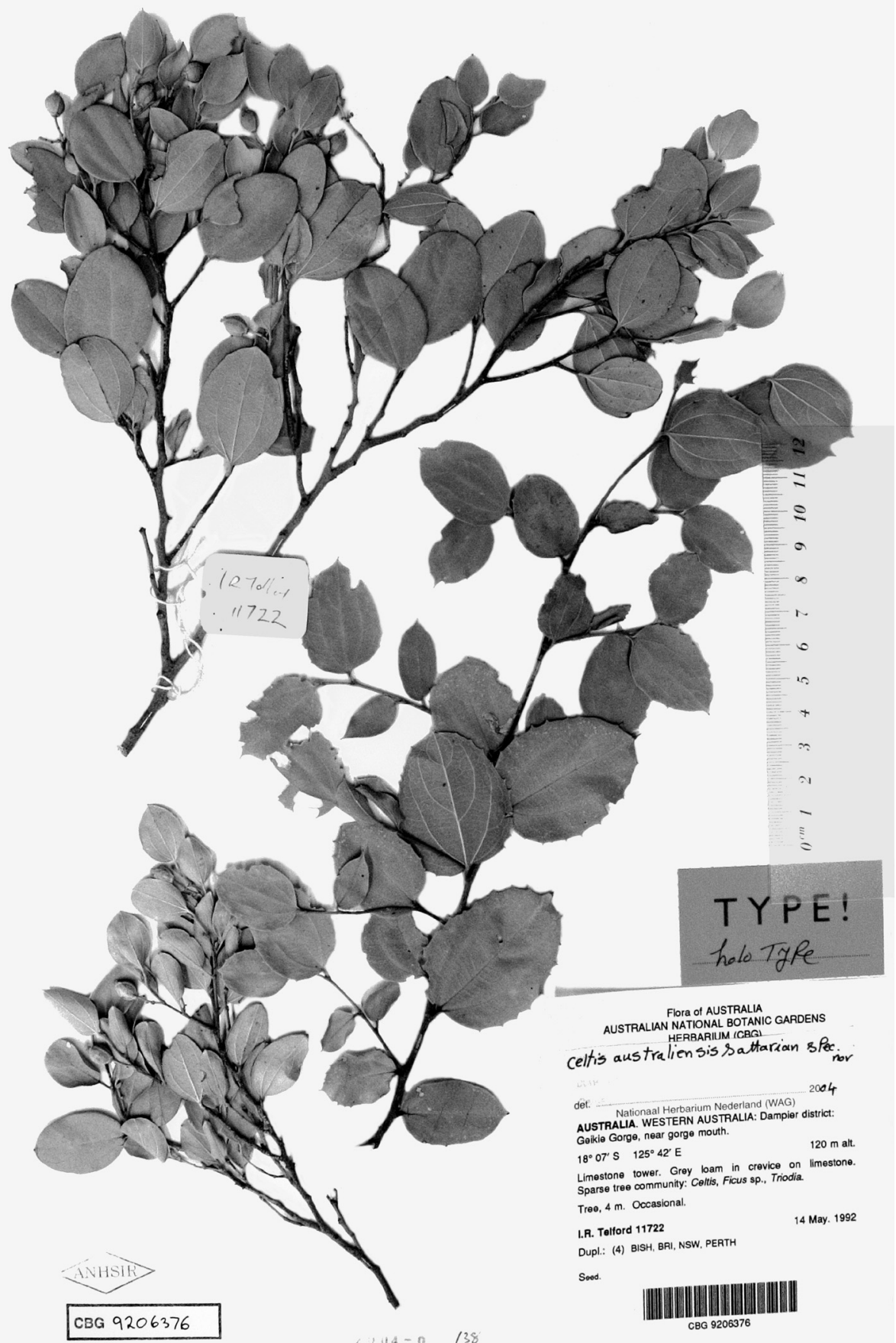

Fig. 1. Celtis australiensis Sattarian. Photograph of holotype specimen Telford 11722. 
or obtuse and spiny, base rounded to cordate, midrib reaching apex, two basal lateral veins reaching $2 / 3$ of leaf, running halfway the distance between midrib and margin, 2-4 additional conspicuous lateral veins, upper leaf surface minutely tuberculate, lower surface more minutely tuberculate, shortly pilose above, more densely so below, midrib pilose to glabrous; watershoot leaves c. 7 by $5 \mathrm{~cm}$. Inflorescence a many-flowered panicle, 3-7 cm long. Male and hermaphrodite flowers white; bisexual perianth lobes ovate-elliptic, 2-2.5 mm long; stamens 1.5-3 mm long, anthers subreniform, stigmatic arms bifid. Fruit an ovoid drupe, c. 7 by $6 \mathrm{~mm}$, green, turning orange to purple, 1-seeded, endocarp (stone) ovoid, surface reticulate, creamy.

Distribution - Australia: Western Australia, Northern Territory, and Queensland.

Habitat \& Ecology - Open places, rocky area on limestone outcrops with Lysiphyllum and Ficus. This species is markedly xerophytic in drier habitats. Flowering: October to November; fruiting: May to July.

Additional specimens examined:

WeSTERn AustRALIA: Chesterfield 389, NE Kimberley, Vansittart Bay (Seaflower Bay), 28 May 1984; Forbes 1997, SE Kimberley, Yards \& Winnama Spring, \pm 17.5 km from Turk Walsh point, Port Warrender, Admiralty Gulf, N Kimberley Creek, 28 May 1984; Forbes 2754, Kimberley, King Leopold range, $1.4 \mathrm{~km}$ W of same Creek on northern side of Gibb River Road, on steep ridge of Mt Bell, 30 July 1984; Streimann 8276, King Leopold Range, gorge 3 km NW of Silent Grove which is 63 km NE of Lennard River crossing on Gibb River Road, 16 May 1988; Kenneally 4347, Drysdale River National Park, E Kimberley, 16 Aug. 1975; Kenneally 5102, Surveyors vine thicket, Mitchell plateau, NW Kimberley, 18 June 1976; Kenneally 5263, Mitchell plateau, NW Kimberley, 22 June 1976; R.A. Perry 2672, 10 miles SW of Lissadell station, 22 June 1976; I.R. Telford 6179, Kimberley district, Carson Escarpment, 35 km E of new Theda, Glider Gorge near Wonjarring, 27 July 1977.

NORTHERn TERRITORY: J.D. Briggs 904, Victoria River district: $5 \mathrm{~km} \mathrm{~S}$ of Timber Creek River Downs, 12 May 1983; Kenneally 5139, Limbunya, 19 June 1976; Kenneally 6186, 7 km SW of Martins well, Dampierland, N of Broome, 26 April 1997; Lazarides 6978, on Stuart Highway, 6 miles NW of Katherine, 10 July 1963; M.O. Parker 832, 23 km S of Katherine, 4 May 1977; R.A. Perry 2394, Port Warrender, vine thicket, 7 miles S of Ord River Station, 8 July 1949; R.A. Perry 2869, 1.5 miles SSE of Timber Creek Police Station, 4 June 1952; Moya Smith 85, Arairma, W of Nellie point, Dampier peninsula, 26 April 1985; H. Streimann 8241, Yammera Gap, Napier range, 9 km NE of Lennard River crossing on Gibb River Road, 12 May 1988.

QueEnSLAND: R.W. Purdie 3597, Burke district, Gregory River, c. $20 \mathrm{~km}$ WSW of Riversleigh Homestead: 5 June 1989.

\section{Celtis madagascariensis Sattarian, spec. nov. - Fig. 2}

$\mathrm{Ab}$ C. philippensis differt foliis ovatis coriaceis integris, apice rotundatis, venis lateralibus marginem fere attingentibus, fructibus rostratis, endocarpio reticulato. - Typus: Phillipson 2938 (holo MO; iso WAG), Madagascar, Toliara, Reserve d'Andohalela, parcelle 2, near Hazofotsy, along river bank, 20 Dec. 1988, fl.

Small tree, 7-10 m high, bark grey, whitish, smooth. Leaves alternate, simple, ovateelliptic, $7-10$ by $2.5-3 \mathrm{~cm}$, coriaceous, petiole $7-14 \mathrm{~mm}$ long, margin entire, attenuate or rounded at base, 3 veins at base, midrib reaching the apex, two lateral veins reaching $2 / 3$ of leaf length, running close to the margin at $1 / 4$ or less of the distance from midrib to margin, no conspicuous additional lateral veins, leaf apex obtuse-mucronate. Inflorescences axillary, as long as or clearly longer than the petiole, lower ones with male flowers only or with male flowers and 1 or 2 hermaphrodite flowers, upper ones sometimes without male flowers and 2-5 hermaphrodite flowers. Male and herma- 


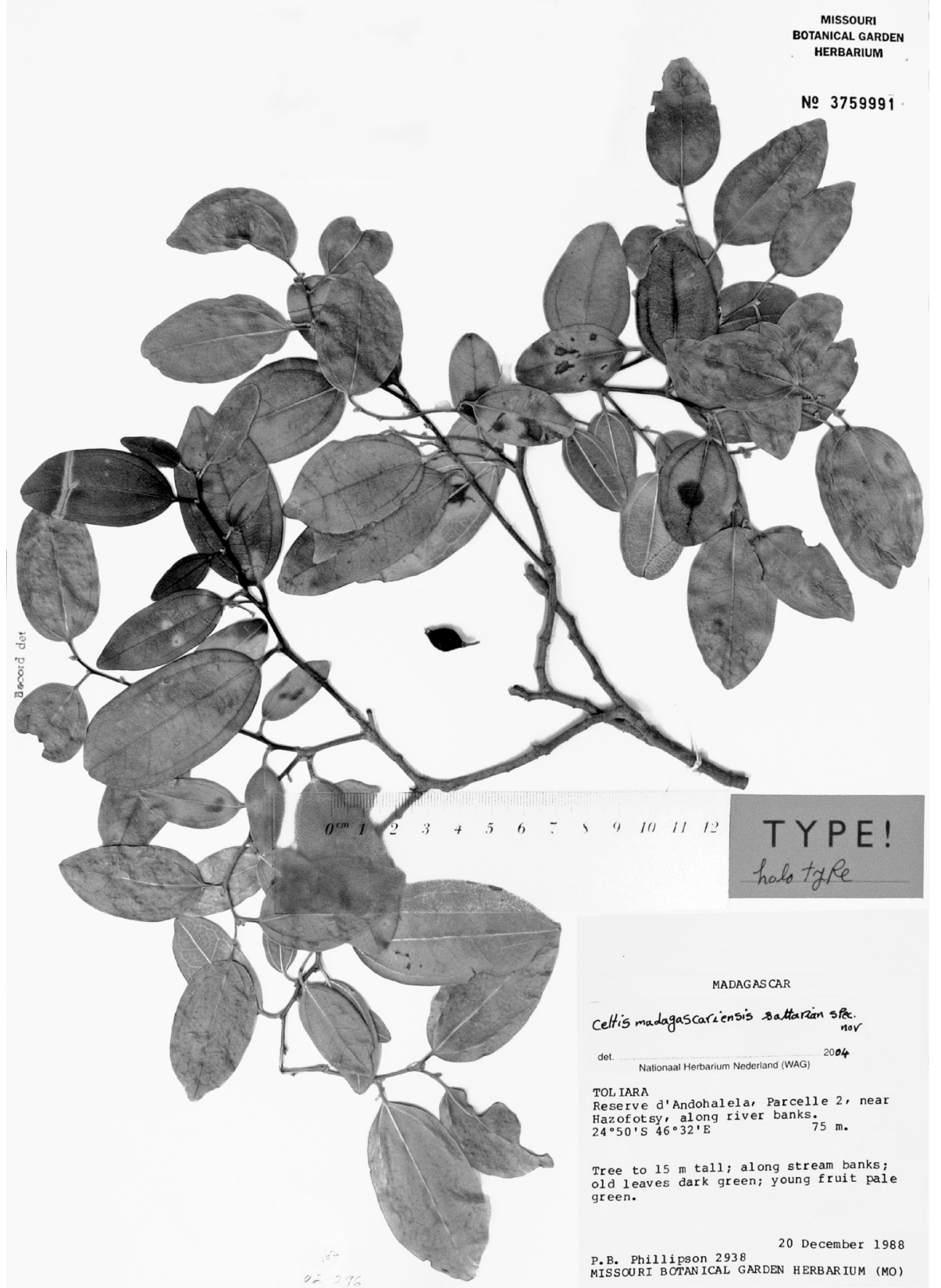

Fig. 2. Celtis madagascariensis Sattarian. Photograph of holotype specimen Phillipson 2938. 
phrodite flowers creamy with a tender glabrous pedicel, 3-5 mm long. Sepals 5, glabrous; stamens 5, filaments shaped as an acumen, often bent during flowering, 5-9 $\mathrm{mm}$ long, anthers $1 \mathrm{~mm}$ long, ovate-globose. Fruit a drupe, broadly ellipsoid, c. 12 by $8 \mathrm{~mm}, 1$-seeded, green becoming red or brown, endocarp ovoid-acuminate, polygonal, surface reticulate, creamy-whitish.

Distribution - Madagascar, Tulear province, Toliara and Toamasina region.

Habitat \& Ecology - Along fast rapids and streams, on calcareous grounds or sandstone. Flowering: end November to end January; fruiting: June to July.

Additional specimens examined:

MADAGASCAR: Linda Sussman 436, Toliar prov., Southern Domain; $40 \mathrm{~km}$ NE of Betioky, near Analafaly; Phillipson 2509, Tulear prov., Beza Mahafaly Reserve, near Betioky Hills E of Sakamena River, near Ambinda, 3 Nov. 1987; Phillipson 2565, Tulear prov., Beza Mahafaly Reserve, near Betioky, Ehazoara River valley E of Sakamena River, 15 Nov. 1987; Roland Rakotondrajaona et al. 117, SE of Ankosy, near National park of Zahamena; R. Randranaivo et al. 496, Toamasina, $1.5 \mathrm{~km}$ of Toliara.

\section{ACKNOWLEDGEMENTS}

This work was carried out as part of a revision of African Celtis and part of a $\mathrm{PhD}$ thesis of the first author. The Government of Iran is gratefully acknowledged for the grant provided. The herbarium custodians of A, ABG, BISH, BRI, CANBA, CBG, DNA, L, MEL, MO, NSW, NT, and PERTH are thanked for their supply of material on loan to Wageningen and Dr. R.H.M.J. Lemmens was so kind to provide the Latin diagnoses.

\section{REFERENCES}

Elias, T.S. 1970. The genera of Ulmaceae in the Southern United States. J. Arnold Arbor. 51: $18-40$.

Grudzinskaya, I.A. 1967. Ulmaceae and reasons for distinguishing Celtidaceae as a separate family Celtidaceae Link. Bot. Zhur. 52: 1723-1748.

Hewson, H.J. 1989. Flora of Australia 3: 29.

Judd, W.S., R.W. Sander \& M.J. Donoghue. 1994. Angiosperm family Paris: Preliminary cladistic analyses. Harvard Pap. Bot. 5: 1-51.

Omori, Y. \& S. Terabayashi. 1993. Gynoecial vascular anatomy and its systematic implications in Celtidaceae and Ulmaceae (Urticales). J. Pl. Res. 106: 249-258.

Polhill, R.M. 1964. Enumeration of the Ulmaceae in Africa South of Sahara. Kew Bull. 19: 139145.

Soepadmo, E. 1977. Ulmaceae. Flora Malesiana 8, 2: 31-76.

Terabayashi, S. 1991. Vernation pattern in Celtidaceae and Ulmaceae (Urticales) and their evolutionary and systematic implication. Bot. Mag. (Tokyo) 104: 1-13.

Ueda, K., K. Kosuge \& H. Tobe. 1997. A molecular phylogeny of Celtidaceae and Ulmaceae (Urticales) based on rbcL nucleotide. J. Pl. Res. 110: 171-178. 